\title{
Pelatihan Penulisan Business Letter Pada Program Keahlian Administrasi Perkantoran di SMK Bhinneka Karawang
}

\author{
Indah Purnama Dewi*, Nina Puspitaloka \\ Universitas Singaperbangsa Karawang \\ Jl. H.S Ronggowaluyo Teluk Jambe Timur Karawang Jawa Barat \\ *E-mail : Indah.purnama@fkip.unsika.ac.id \\ DOI: https://doi.org/10.21107/pangabdhi.v6i2.8165 \\ Naskah diterima 10 Agustus 2020, Revisi 5 September 2020, Terbit 29 Oktober 2020
}

\begin{abstract}
Abstrak
Kemampuan berbahasa Inggris adalah persyaratan yang banyak muncul di setiap lowongan pekerjaan. Sementara itu, Peserta didik di SMK Bhinneka Karawang masih kurang memiliki minat dalam menulis teks berbahasa Inggris. Peserta didik selalu beranggapan bahwa menulis surat-surat formal berbahasa Inggris sangat sulit karena kebanyakan dari mereka tidak menguasai kosakata yang tepat untuk membuat kalimat yang baik. Oleh karena itu dosen-dosen Universitas Singaperbangsa mengadakan pengabdian kepada masyarakat di SMK Bhinneka Karawang dalam bentuk pelatihan penulisan business letter untuk peserta didik kelas XII pada program keahlian Administrasi Perkantoran. Pelatihan dan pendampingan dilakukan sebanyak 3 kali setiap hari sabtu. Metode yang digunakan dalam penelitian ini adalah Model ADDIE yang meliputi: (1) Analisis, (2) Rancangan (3) Pengembangan, (4) Implementasi, dan (4) Evaluasi. Berdasarkan kegiatan yang telah dilakukan dapat disimpulkan bahwa: (1) Pelaksanaan pelatihan sangat mendukung kegiatan belajar mengajar peserta didik di kelas, (2) peserta didik sangat bersemangat dalam melakukan pelatihan. Hal ini memberikan ide bahwa sangat perlu dilakukan pelatihan penulisan business letter bagi peserta didik program keahlian Administrasi Perkantoran di sekolah-sekolah lain dengan harapan para peserta didik mendapatkan bekal, nilai tambah dan kompetensi baru dalam meningkatkan kualitas pembelajaran bahasa Inggris.
\end{abstract}

Kata Kunci: pelatihan, penulisan, business letter, bahasa Inggris

\begin{abstract}
English proficiency is a requirement that appears in many job vacancies. Meanwhile, Students at SMK Bhinneka Karawang lack of interest in writing English texts. Students always thought that writing bussines letter is very difficult because most of them did not master the proper vocabulary to make good sentences. Therefore, the lecturers of Singaperbangsa University held community service at SMK Bhinneka Karawang in the form of business letter writing training for class XII students in the Office Administration program. Training and mentoring were carried out 3 times every Saturday. Method in this training used in this study is the ADDIE Model which includes: (1) Analysis, (2) Design, (3) Development, (4) Implementation, and (4) Evaluation. Based on the activities that have been carried out, it can be concluded that: (1) The implementation of training is very supportive of the teaching and learning activities of students in class, (2) students are very enthusiastic in conducting training. This gave an idea that it is very necessary to conduct business letter writing training for students in the Office Administration program in other schools with hope that the students will get supplies, added value and new competencies in improving the quality of learning English.
\end{abstract}

Keywords: training, writing, business letter, English

\section{PENDAHULUAN}

Saat ini, kemampuan berkomunikasi dengan menggunakan bahasa Inggris merupakan kecakapan yang sangat penting dalam pergaulan sehari-hari, baik di lingkungan masyarakat maupun dilingkungan dunia usaha. Hampir semua dunia usaha atau perusahaan menggunakan bahasa Inggris sebagai alat ukur untuk tes masuk ke dalam sebuah perusahaan.
Akan tetapi berkomunikasi dengan menggunakan bahasa Inggris bukanlah hal yang mudah.

Untuk itu, sudah seharusnya permasalahan tersebut di atas menjadi perhatian kita bersama dalam rangka peningkatan kemampuan berbahasa Inggris. Termasuk bagi para lulusan Sekolah Menengah Kejuruan (SMK), dimana para peserta didik akan bersaing dengan sesama lulusan lain dan dengan lulusan pendidikan yang 
lebih tinggi baik dari dalam maupun luar negeri

Lulusan SMK harus memiliki kualitas yang unggul di bidang vokasi dan bidang penunjang lainnya yang bersifat universal yaitu kemampuan komunikasi secara internasional menggunakan bahasa Inggris. Hal ini dikarenakan kemampuan berbahasa Inggris adalah persyaratan yang secara frekuensi lebih banyak muncul di setiap lowongan pekerjaan dengan yang ada. Bidang keahlian apa pun, jika ditunjang dengan kemampuan bahasa Inggris akan menjadi daya saing yang signifikan di pasar kerja.

Keterampilan berbicara sesungguhnya bukanlah satu-satunya keterampilan yang berperan pada dunia kerja karena keterampilan menulis berbahasa Inggris juga sangat diperlukan dalam segala profesi di dunia global saat ini. Menulis menurunkan atau melukiskan lambanglambang grafik yang menggambarkan suatu bahasa yang dipahami seseorang, sehingga orang lain dapat membaca grafik tersebut kalau mereka memahami bahasa dan gambaran grafik itu (Tarigan, 2008). Pendapat lain mengatakan menulis berarti mengorganisasikan gagasan secara sistematis serta mengungkapkan secara tersurat (Sambodi, 2015).

Kegiatan menulis sangat penting untuk dilatih karena sebagai alat komunikasi secara tertulis dalam menyampaikan informasi yang sangat penting yang berkaitan dengan dunia usaha atau industri. Berdasarkan hal-hal tersebut, SMK yang khususnya termasuk dalam program keahlian administrasi perkantoran akan dihadapkan pada penulisan surat-surat bisnis, memo, maupun menulis laporan-laporan berbahasa Inggris di dunia usaha atau dunia industri.

Dalam pengabdian kepada masyarakat ini SMK Bhinneka Karawang menjadi objek dalam kegiatan yang diselenggarakan oleh dosen-dosen program studi bahasa Inggris, Universitas Singaperbangsa Karawang. SMK Bhinneka Karawang ini secara umum belum memiliki kemampuan berbahasa Inggris yang baik, dalam berbicara maupun dalam tulisan. Kemampuan memahami bahasa Inggris para peserta didik masih berada pada level pre-intermediate (menuju level menengah), dimana seharusnya kemampuan berbahasa Inggris kelas XIII berada pada level pre-advance. Hal ini terjadi karena kurangnya minat peserta didik dalam menulis teks berbahasa Inggris yang kemudian dituangkan dalam penulisan surat-surat formal. Peserta didik selalu beranggapan bahwa menulis surat-surat formal berbahasa Inggris sangat sulit karena tidak menguasai vocabualry yang tepat untuk membuat kosakata yang baik.

Tujuan kegiatan pengabdian masyarakat ini adalah memberikan pelatihan bagi peserta didik di tingkat SMK pada program keahlian Administrasi Perkantoran dalam hal menulis surat bisnis. Kegiatan pengabdian masyarakat ini diharapkan dapat memberikan pengetahuan mengenai tata cara penulisan surat bisnis yang baik dan benar sehingga peserta didik di SMK Bhinneka memiliki kemampuan dalam hal menulis umumnya atau menulis surat bisnis khususnya dapat tergali dengan baik.

\section{METODE}

Pelaksanaan pengabdian ini dilaksanakan di SMK Bhinneka Karawang, Jl. Kertabumi No. 42 Karawang. Peserta yang mengikuti pelatihan ini adalah peserta didik pada program keahlian Administrasi Perkantoran. Alasan Pemilihan lokasi pengabdian ini adalah karena di sekolah tersebut banyak guru yang belum memiliki keterampilan tentang penulisan business letter atau surat-menyurat formal dengan menggunakan bahasa Inggris

Pelatihan ini diadakan sebanyak tiga kali pertemuan yaitu mulai tanggal 8, 15, 22 Februari 2020. Adapun metode yang digunakan dalam penelitian ini adalah Model ADDIE yang meliputi: (1) Analysis (Analisis), (2) Design (Desain), (3) Develop (Pengembangan), (4) Implementation (Implementasi), dan (4) Evaluation (Evaluasi).

Dalam pelatihan ini dibutuhkan beberapa peralatan dan bahan sebagai penunjang dalam kegiatan pengabdian kepada masayarakat tersebut. Alat dan bahan yang digunakan yaitu: (1) laptop sebagai media untuk menulis surat dalam bentuk email. (2) Kertas Polio bergaris untuk menulis surat yang dapat digunakan untuk bukti fisik dokumen, (3) buku referensi sebagai contoh materi dalam pelatihan.

\section{HASIL DAN PEMBAHASAN}

Kegiatan pelatihan dan pendampingan penulisan business letter ini melibatkan 2 orang dosen dan 2 orang mahasiswa program studi pendidikan bahasa Inggris. Sedangkan peserta dari pelatihan ini adalah peserta didik pada program keahlian Administrasi Perkantoran di SMK Bhinneka Karawang. Kegiatan ini diawali dengan koordinasi kepada kepala sekolah dan wakil kepala sekolah bidang kurikulum yang 
kemudian dilanjutkan dengan pelatihan dan pendampingan penulisan business letter pada peserta didik program keahilian Administrasi Perkantoran di SMK Bhinneka Karawang.

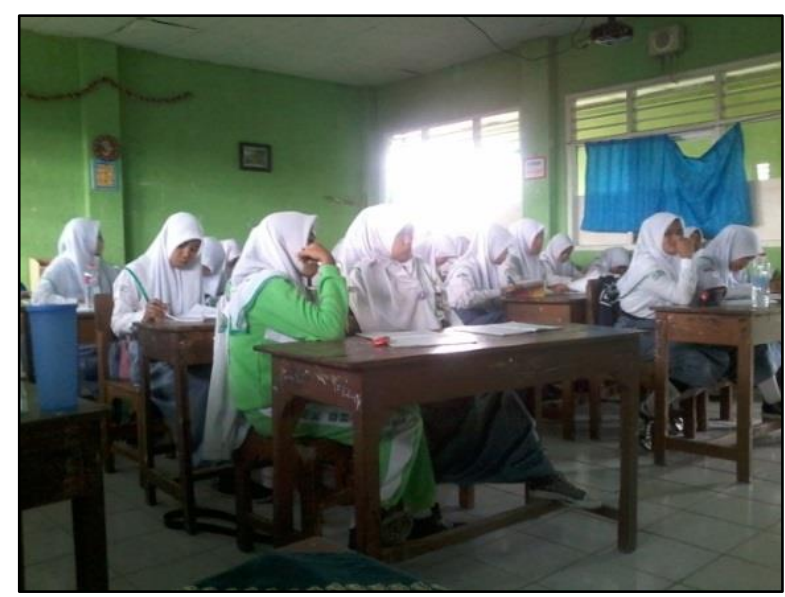

Gambar 1. Peserta Didik Dibekali dengan Teori Tentang Business Letter

Pada tahapan pertama, analisis kondisi di tempat pelatihan dilakukan dalam rangka mengetahui permasalahan apa saja yang ada di sekolah tersebut. Hal ini dilakukan agar pelatihan dapat dilaksanakan dan dapat memberikan solusi dari permasalahan yang ada. Adapun permasalahan yang terdapat di tempat pelatihan antara lain: rendahnya minat dan motivasi peserta didik dalam menulis bahasa Inggris khususnya dalam menulis business letter, serta kurangnya keterampilan guru mata pelajaran Bahasa Inggris dalam menyampaikan materi tentang business letter pada program keahlian Administrasi Perkantoran.

Tahapan selanjutnya adalah pengembangan. Setelah mengetahui permasalahan dan membuat desain penelitian, pengembangan dilakukan untuk memberikan pengetahuan yang ada dalam pelatihan. Dalam hal ini, pengembangan dilaksanakan dengan cara memberikan pelatihan berupa pelatihan menulis business letter.

Setelah melakukan tahap pengembangan, tahapan selanjutnya adalah implementasi. Pada tahapan ini, terdapat beberapa kegiatan yang dilaksanakan. Kegiatan pertama yaitu pemaparan materi dengan metode ceramah mengenai media pembelajaran yang akan dibuat dalam pelatihan. Pada kegiatan ini, peserta dibekali pengetahuan mengenai English business letter secara umum dan membahas mengenai beberapa hal antara lain pengenalan apa yang dimaksud dengan business letter, bagian-bagian dari business letter serta contoh-contoh business letter seperti Writing claim letters Requesting a service,
Ordering supplies, Confirming services Confirming order, Adjustment Letter, Reminder, Thank you for your paymen, Company Purchase Order Sample, Inquiry Letters, Follow-Up Letters, Recommendation Letters, Resignation Letters, Application and Cover Letters, dan Standard speculative letter.

Pelatihan ini berlangsung secara interaktif dan komunikatif antara pemateri dan peserta. Materimateri yang disampaikan menggunakan metode ceramah melalui presentasi Microsoft Power Point. Setelah pemaparan materi dari narasumber, para peserta juga diminta untuk mempraktekkan menyusun salah satu business letter dengan memperhatikan penjelasan dari narasumber dan contoh-contoh yang terdapat di modul.

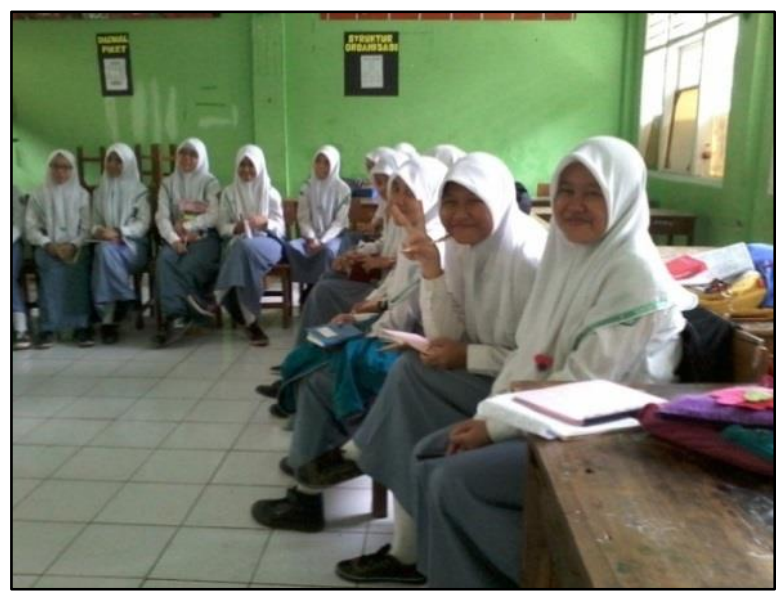

Gambar 2. Peserta Mengimplementasikan

Pembuatan Business Letter

Pada tahapan terakhir yaitu evaluasi dan monitoring. Tim pelaksana mengukur keberhasilan peserta pelatihan dalam membuat business letter yang dapat digunakan sebagai pendukung proses pembelajaran bahasa Inggris serta menganalisis hambatan untuk kelanjutan kegiatan.

\section{KESIMPULAN}

Berdasarkan kegiatan yang telah dilakukan dapat disimpulkan bahwa: (1) Pelaksanaan pelatihan sangat mendukung kegiatan belajar mengajar peserta didik di kelas, (2) peserta didik sangat bersemangat dalam melakukan pelatihan. Hal ini memberikan ide bahwa sangat perlu dilakukan pelatihan penulisan business letter bagi peserta didik program keahlian Administrasi Perkantoran di sekolah lain dengan harapan para peserta didik mendapatkan bekal, nilai tambah dan kompetensi baru dalam meningkatkan kualitas pembelajaran bahasa Inggris. 


\section{UCAPAN TERIMA KASIH}

Terima kasih kepada SMK Bhinneka Karawang yang telah membantu dan berkontribusi di dalam kegiatan pengabdian kepada masyarakat ini.

\section{DAFTAR PUSTAKA}

Arum, S. 2020. Pelatihan Bahasa Inggris Business Letter Writing untuk Meningkatkan Daya Saing Pelaku UMKM dalam Pemasaran Produk Di Bisnis Global. Jurnal Abdinus: Jurnal Pengabdian Nusantara. Vol 3 (2). 148-155 pp.

Diselita, R \& Saharudin. 2011. Pengembangan Modul Menulis Surat Bisnis Bahasa Inggris Untuk Kelas XII Sekolah Menengah Kejuruan. Tekno-Pedagogi. Vol. 1. 71-80 pp.

Setiawan, E., Rahman, D \& Kristanto, R. 2020.
Pelatihan Keterampilan Menulis dalam Korespondensi Berbahasa Inggris, Menerjemahkan serta Keterampilan Menggunakan Grammarly, Google Translate, dan Google Drive di Sekolah Menengah Kejuruan Rawasari Jakarta Pusat. KSATRYA Vol. 2. DO 10.31334/jks.v2i2.733

Martono. E. 2016. Modul Guru Pembelajar SMK: Kompetensi Profesional: Surat Menyurat Bahasa Inggris

Tarigan, H.G. 1984. Menulis Surat Keterampilan Berbahasa. Bandung : Angkasa

Sambodi. 2015. Pembelajaran dengan Teknik Pelatihan Untuk Meningkatkan Kemampuan Menulis Surat Pribadi pada Siswa Kelas VII C SMP Negeri 9 Kota Jambi Tahun Pelajaran 2014/2015. Jurnal Ilmiah Dikdaya. Vol 9 (1). 